\title{
頸動脈小体腫瘍を伴ら迷走神経傍神経節腫例
}

\author{
楯谷 一郎1) - 安里 亮1) 庄司 和彦2) - 加茂 康樹3) \\ 岸本 正直 ${ }^{4)}$ ・児嶋 久剛1) $\cdot$ 白瀬 智之 ${ }^{5)}$
}

\section{Multiple Paraganglioma of the Vagus Nerve and the Carotid Body; A Case Report}

\author{
Ichiro Tateya, Ryo Asato, Hisayoshi Kojima and Tomoyuki Shirase \\ (Kyoto University) \\ Kazuhiko Shoji \\ (Shimane Prefectural Central Hospital) \\ Yasuki Kamo \\ (Shiga Medical Center for Adults) \\ Masanao Kishimoto \\ (Shimada Municipal Hospital)
}

\begin{abstract}
A rare case of paraganglioma arising in the vagus nerve and carotid body is reported. A tumor occupying the right parapharyngeal space was revealed incidentally by computed tomography in a 46 year-old woman. The tumor was located between the common carotid artery and the internal jugular vein and was removed transcervically with vagus nerve. After the operation, Horner's symptom and hoarseness occurred and thyroplasty was performed. Six months after the operation, a right neck mass occurred and angiography showed a high vascular tumor in the widened carotid bifurcation. The tumor was resected transcervically. The patient's elder brother had also exhibited a glomus-jugular tumor and had died of intracranial invasion. This case is the first familial case and the third multiple case of vagal paraganglioma reported in Japan.
\end{abstract}

Key words : multiple paraganglioma, vagus nerve, carotid body, familial

はじめに

頭頸部領域に発生する傍神経節腫は比較的まれな疾患 であるが，その多くは頸動脈小体腫瘍や頸静脈鼓室傍神 経節腫であり，迷走神経由来のものはまれである。また， 傍神経節腫は多発例や家族発生例があることが知られて いる1)が，迷走神経傍神経節腫を含む多発例，家族発生 例は非常にまれであり，われわれの渉猟し得た範囲では 本邦での報告は多発例が 2 例のみで，家族例は認めてい
ない，今回われわれは頸動脈小体腫瘍を合併し，家族例 がみられた迷走神経傍神経節腫の 1 例を経験したので報 告する.

症例：46歳, 女性.

$$
\text { 症例 }
$$

既往歴 : 特記すべきことなし。

家族歴：兄が25年前に頸静脈鼓室傍神経節腫をきたし，

5）京都大学医学部附属病院病理部

4）島田市民病院耳鼻咽啹科 

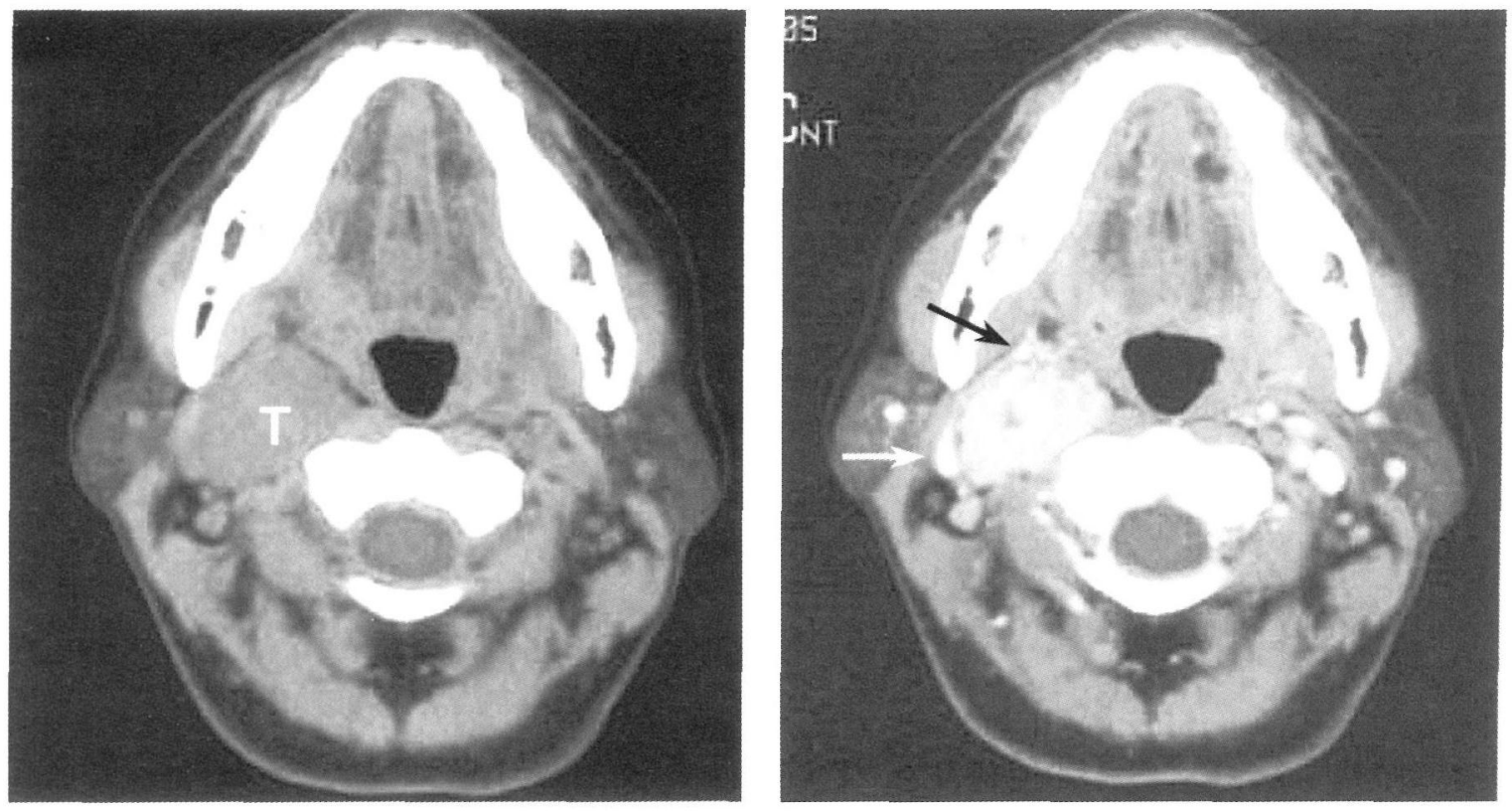

図 1 頸部 $\mathrm{CT}$ 像 (左: 単純, 右: 造影)

右副咽頭間隙に直径 $4 \mathrm{~cm}$ の腫瘍陰影 ( T ) を認める. 腫瘍は頸動脈(黒矢印), 内頸静脈(白矢印)を左右に分け て圧排して打り, 強い造影効果を認める.

頭蓋底進展の後に腫瘍からの出血により死亡している.

現病歴: 平成 9 年 4 月, 咽頭痛飞て他院呼吸器科を受 訬した際，頸部腫瘤を指摘された、頸部 CT を施行した ところ右副咽頭間隙腫瘍を指摘されたため, 平成 9 年 5 月19日京都大学附属病院耳鼻咽喉科を紹介受診した.

治療経過: 初診時, 右下顎角後方硬結を触孔, 中咽 頭腔右側壁の軽度腫脹を認めた。頸部 CT (図 1 ) とて右 副咽頭間隙に直径 $4 \mathrm{~cm}$ の造影効果の两る腫瘍陰影を認 めた。腫瘍は頸動脈, 内頸静脈を左右に分けて圧排して 扣り，冠状断 MRI（図 2 )では頭蓋底近くまで進展する 陰影が観察された。迷走神経あるいは交感神経由来の神 経原性腫瘍, 特飞神経鞘腫を疑い平成10年 5 月11日, 摘 出術を施行した（図３）。腫瘍は右副咽頭間隙に存在し, 総頸動脈, 内頸静脈の間飞位置していた。また下端は迷 走神経に移行して呿り, 迷走神経は腫瘍下端より約 7 $\mathrm{cm}$ にわたって肥厚していた。被膜下摘出を試みたが被 膜との癒着が強く, また易出血性であったため核出は困 難であった。腫瘍の一部を術中迅速病理に出したところ， 傍神経節腫の疑いであった。腫瘍下端を迷走神経ととも に摘出し，上方へと剥離を進めた。 上万へは頸静脈孔直 下まで進展していたが，頸部外切開法にて迷走神経とと

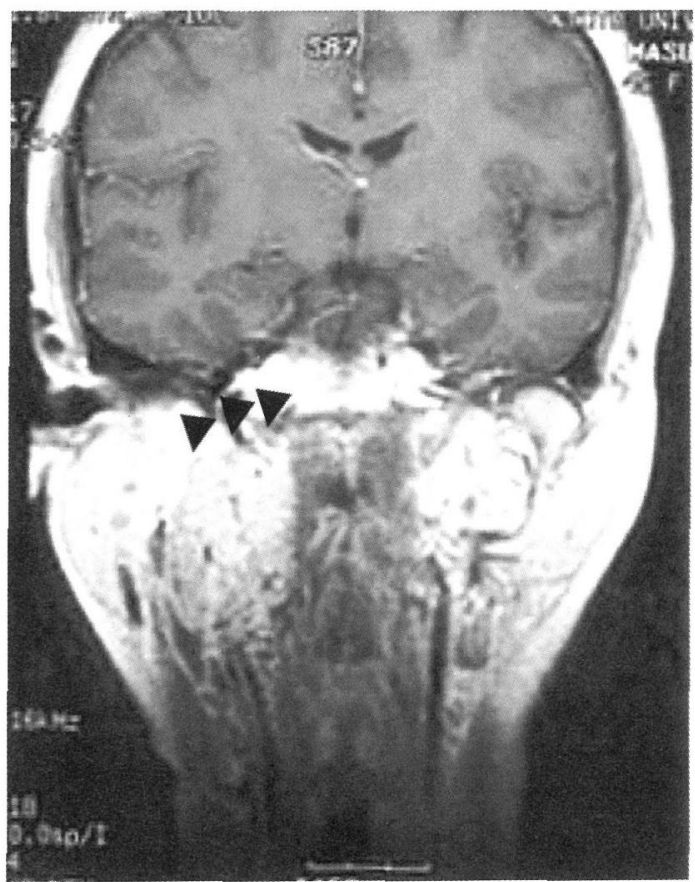

図 2 冠状断 MRI T1 強調像 内部が不均一を腫瘍陰影を認める。腫瘍は頭蓋底近くま で存在している(黒短). 


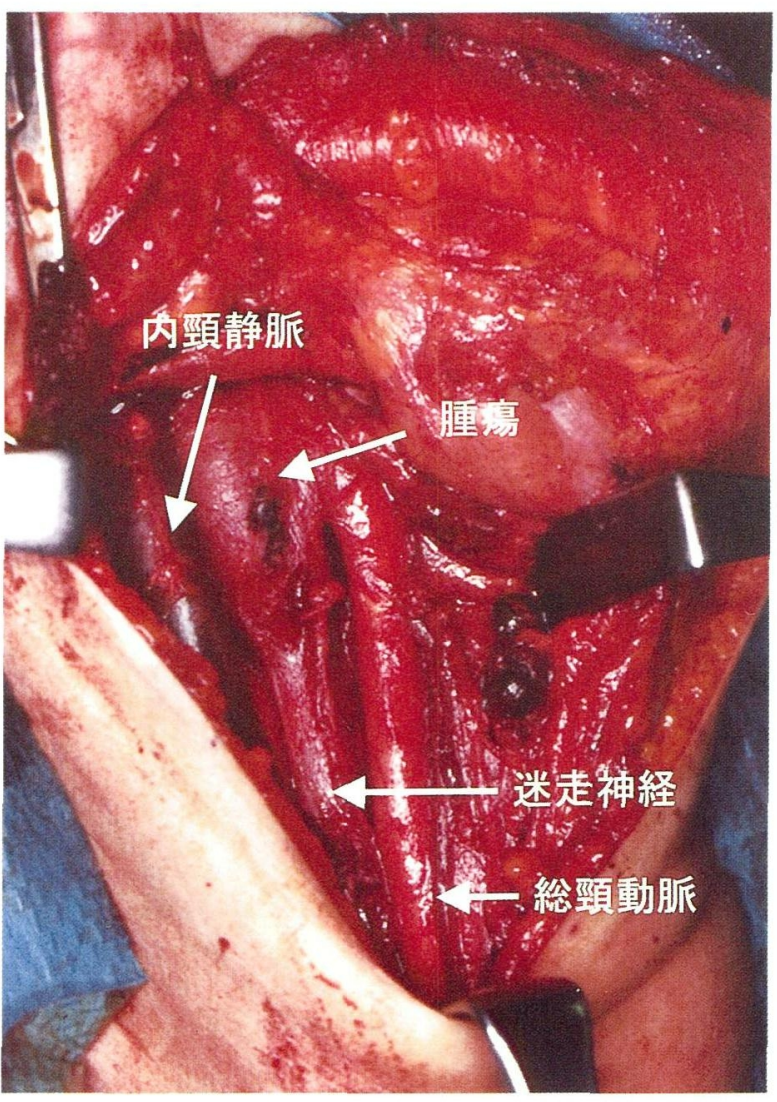

図 3 術中所見

腫瘍は右副咽頭間隙に存在し, 総頸動脈, 内頸静脈の間 に位置していた，下端は迷走神経に移行して批り，迷走 神経は腫瘍下端より約 $7 \mathrm{~cm}$ にわたって肥厚していた。

もに摘出乙得た。腫瘍は直径 $4.9 \times 2.7 \times 2.4 \mathrm{~cm}$ で, 割 面は暗赤色, 内部はやや不均一であった(図 4 ). 永久病 理診断は傍神経節腫であった。術後ホルネル徴候, 右舌 咽神経麻瘴ならびに右反回神経麻痺を生じたため, 音声 改善を目的に甲状軟骨形成術を追加した，以後外来にて 経過観察していたが，術後半年より右頸部腫瘤が出現し た。頸部 CT (図 5 )を施行したところ，右頸動脈分岐部 飞外頸動脈, 内頸動脈を前後に分㺭て圧排与る腫瘍陰影 を認め, 頸動脈小体腫瘍を疑い摘出術を施行した。な拉 術前の血圧は正常で血中，尿中カテュラミン值の異常高 值も認めなかった。腫瘍は直径 $1.2 \mathrm{~cm}$ で頸動脈分岐部 飞存在して和り, 内頸動脈を温存しつつ摘出し得た. 永 久病理診断にて頸動脈小体由来の傍神経節腫の確定診断 を得た。現在外来にて経過観察中であるが，他の部位も 含め再発は認めていない.
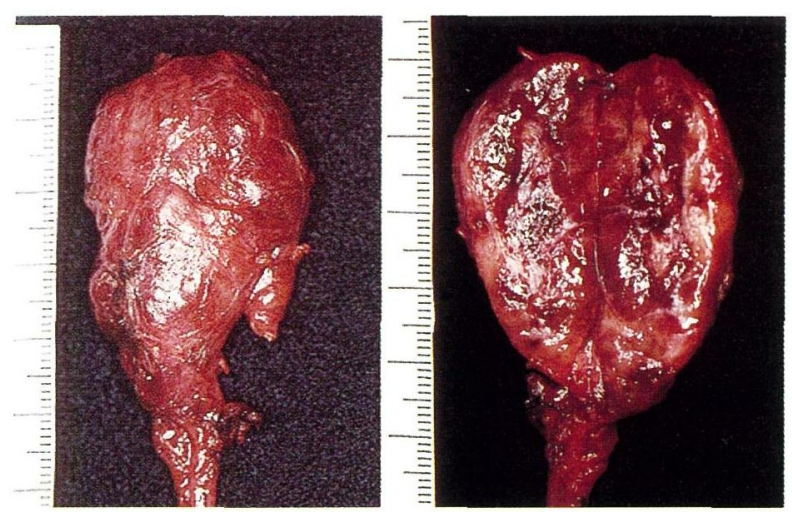

図 4 摘出標本

腫瘍は直径 $4.9 \times 2.7 \times 2.4 \mathrm{~cm}$ で, 割面は暗赤色, 内部 はやや不均一であった

病理組織所見 ( 1 回目手術時, HE 染色; 図 6$)$ ：細胞 質に富み，類円型の大小不同な核を持つ細胞が傍神経節 腫に特徵的ないわゆる cell-ball を形成していた. 分裂像 は認めず，また間質には豊富な毛細血管を認めた。

免疫組織学的所見 (図 7 ): 神経原性腫瘍のマーカーと される，クロモグラニン，NSE，S-100 そて陽性所見を 示した。

\section{考察}

傍神経節腫は比較的るれな神経原性腫瘍であり, 頭頸 部では頸動脈小体, 頸静脈球, 迷走神経傍神経節, 喉頭 傍神経節などの傍神経節組織から発生するとされてい $ろ^{2)}$. 迷走神経傍神経節腫は迷走神経の下神経節あるい はその周囲の神経周膜内より生じ，一般には紡錘形を呈 するが，迷走神経のあらゆる領域に発生し得ると考光ら れている2). 本邦ではわれわれの渉猟し得た範囲では2 5 例2) 23) の報告があるのみでまれな疾患とい光る，以下 に過去の本邦報告例(表 1 )をるとに迷走神経傍神経節腫 の臨床像につき自験例を含めて考察した。

\section{1) 年齢，性差}

発症年齢は22〜 71歳と広範囲にわたって挆り, 平均年 齢は52歳であった. 男女比は判明分では男性 6 例, 女性 18例と女性に多い傾向であった。

\section{2) 臨床症状}

ほとんどの症例が頸部腫瘤を主訴に来院していたが, 記載のあった 21 例中 9 例飞迷走神経麻痺, 副神経, 舌下 神経などの脳神経症状を術前から認めていた。神経鞘腫 

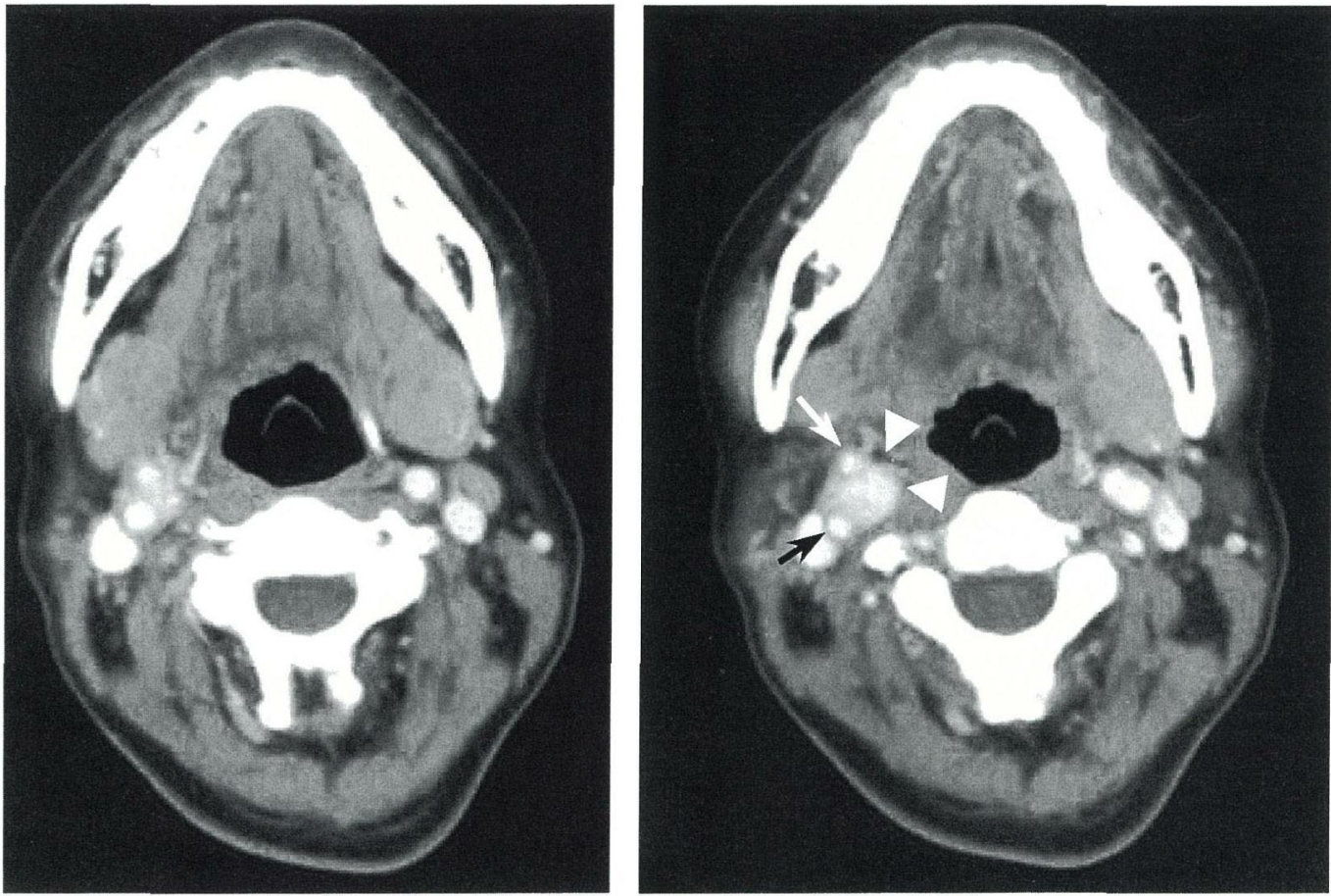

図 52 回目術前頸部造影 $\mathrm{CT}$ 像

右頸動脈分岐部に外頸動脈(白矢印)，内頸動脈(黒矢印)を前後に分けて圧排する造影効果のある腫 瘍陰影(白矢頭)を認める。
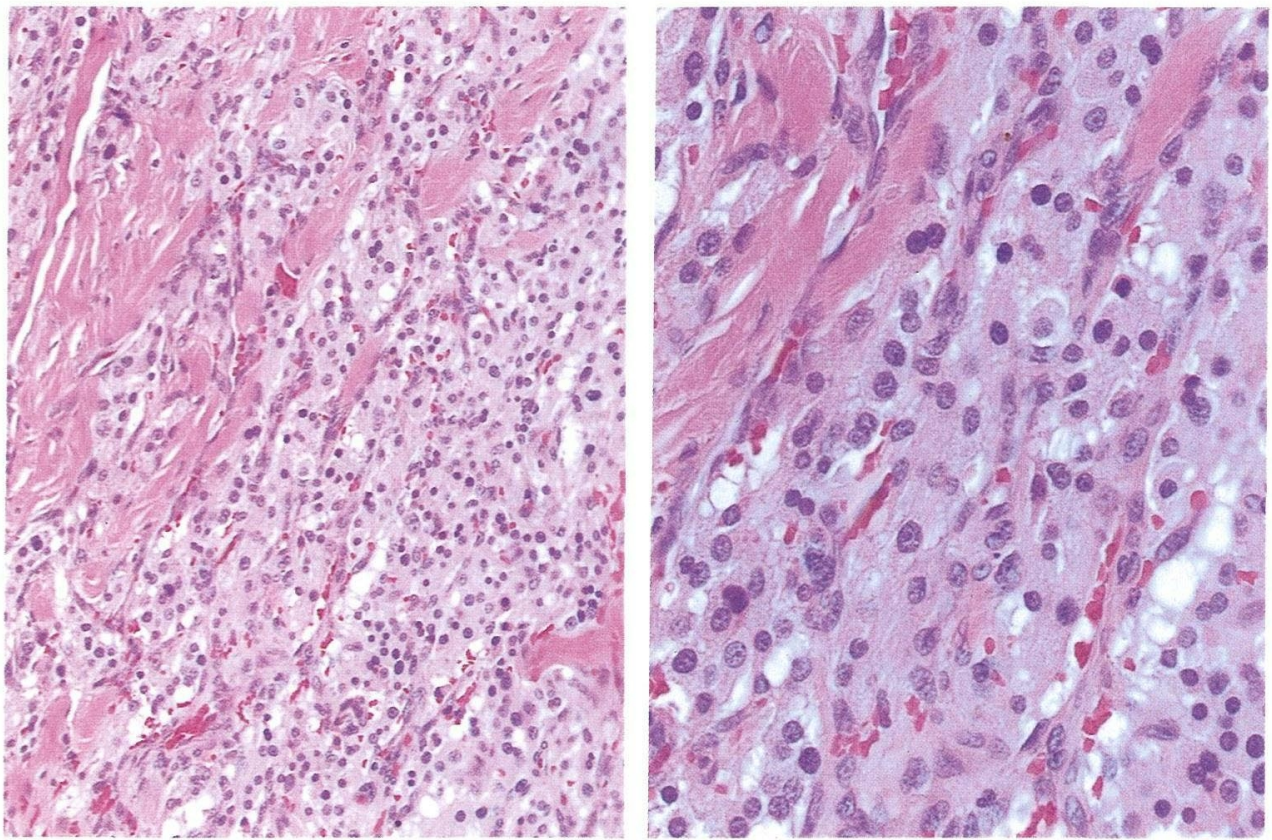

図 6 永久病理学的所見 $(\mathrm{HE}$ 染色, 左 : $\times 100$, 右 : $\times 400)$

細胞質に富み，類円型の大小不同な核を持つ細胞が傍神経節腫に特徵的な cell-ball を形成し ている、核分裂像は認めない。間質には豊富な毛細血管を認める。 

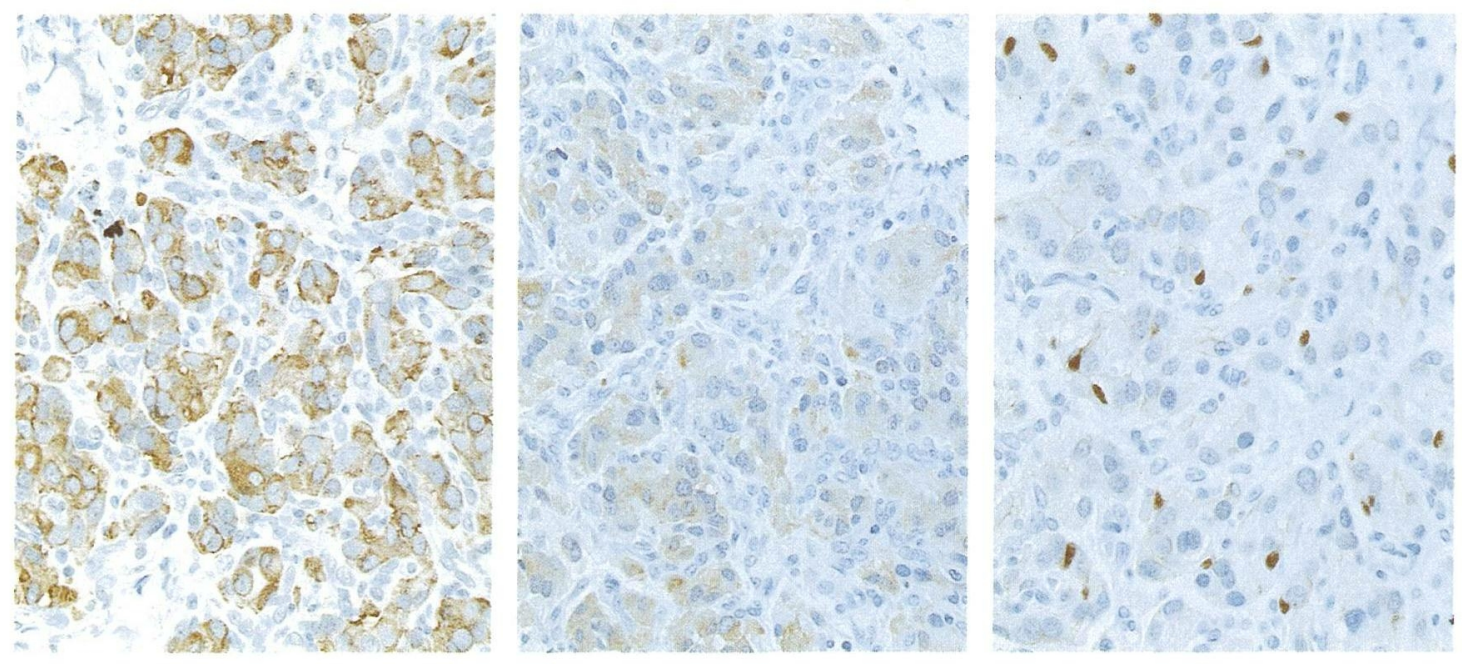

図 7 免疫組織学的所見 (左 : クロモグラニン, 中 : NSE, 右 : S-100)

神経原性腫瘍のマーカーとされる, クロモグラニン, NSE, S-100にて陽性を示す.

と異なり，術前に神経麻痺をきたしやすい傾向であった。

3 ) 術前診断

触診所見としては左右には可動性を認めるが，上下方 向には認めないことが神経原性腫瘍の診断の一助となる. さらに画像所見では頸動静脈の圧排方向が重要であり, 迷走神経原性腫瘍の場合 CT あるいは MRI で頸動脈之 内頸静脈を分けて圧排する像を呈することが特徴的であ る. 神経原性腫瘍で鑑別すべきものは神経鞘腫である. MRI ではともに T1 強調像で低〜中信号, T2 強調像で 中〜高信号を呈するが，傍神経節腫は血流が豊富であり， 腫瘍内の栄養血管が無信号領域として描出され, 典型的 には salt and pepper appearance を呈する24). CTでも 傍神経節腫は神経鞘腫に比して強い造影効果を示し, 内 部の性状は神経鞘腫では中心性壊死を伴いやすいとされ ている15). 血管造影は傍神経節腫の術前診断には必須の 検査とされて括り, 本邦でる判明分23例中 20 例に行われ ていた．血管造影の所見としては頸動脈分岐部よりやや 上万に tumor stain を認めること, 内外頸動脈の軽度圧 排を認めるものの, 分岐部の拡大を認めないことが特徵 とされる12). 栄養血管は外頸動脈系で, 後頭動脈, 上行 咽頭動脈, 後耳介動脈, 顎動脈などが報告されている. 自験例では血管造影は施行しなかったが，CT で造影効 果を認めたことから血管造影を行って扣れば術前診断が できた可能性があり, 反省点と考光ている，CT, MRI で神経原性腫瘍が疑われ, 造影効果が強い場合には傍神
経節腫を念頭に打いて血管造影を行う必要があると思わ れる. 後述の通り, 治療を考觉た上でも血管造影は必須 であろう。血管造影の他, 術前診断として朝陰ら ${ }^{14)}$ は ダイナミック CT, Furukawa ら ${ }^{20)}$, 田ロら ${ }^{2)}$ はカラー ドップラーェコーが有用であったと報告している。

4) 治療法・予後

傍神経節腫はしばしば悪性例を認めることが知られて 特り，その頻度は海外では８１9\% と報告されている25). 本邦でも斎藤ら がが初回手術の 2 年半後に頸部リンパ節 転移を認めた症例を報告して物り，傍神経節腫は基本的 に手術適応と思われる。術式としては頸部外切開法, 下 顎骨離断法，側頭下窩法などが報告されているが，本邦 報告例ではその内訳は頸部外切開法15例, 下顎骨離断法 6例, 側頭下窝法1例であった。術後の神経麻㿉は記載の あった20例中, 自験例も含めて18例とほぼ全例に新たに 発生して扮り, 神経麻痺の合併に関しては術式による成 績の違いはなかったが, 頸部外切開を行ったうち 3 例が 部分切除飞終っていた. 迷走神経傍神経節腫は副咽頭間 隙に存在しているため上方の視野が取りにくく，腫瘍が 巨大である場合や頭蓋底直下まで進展している場合には 腫瘍上端で盲目的操作を強いられることが多い，さらに 傍神経節腫は易出血性であるため, 良好な視野が得られ ない場合は積極的に下顎骨離断法を併用すべきであるう。 自験例でも頭蓋底近くまで進展していたため場合によっ ては下頂骨離断を行う予定であったが，結果的に頸部外 


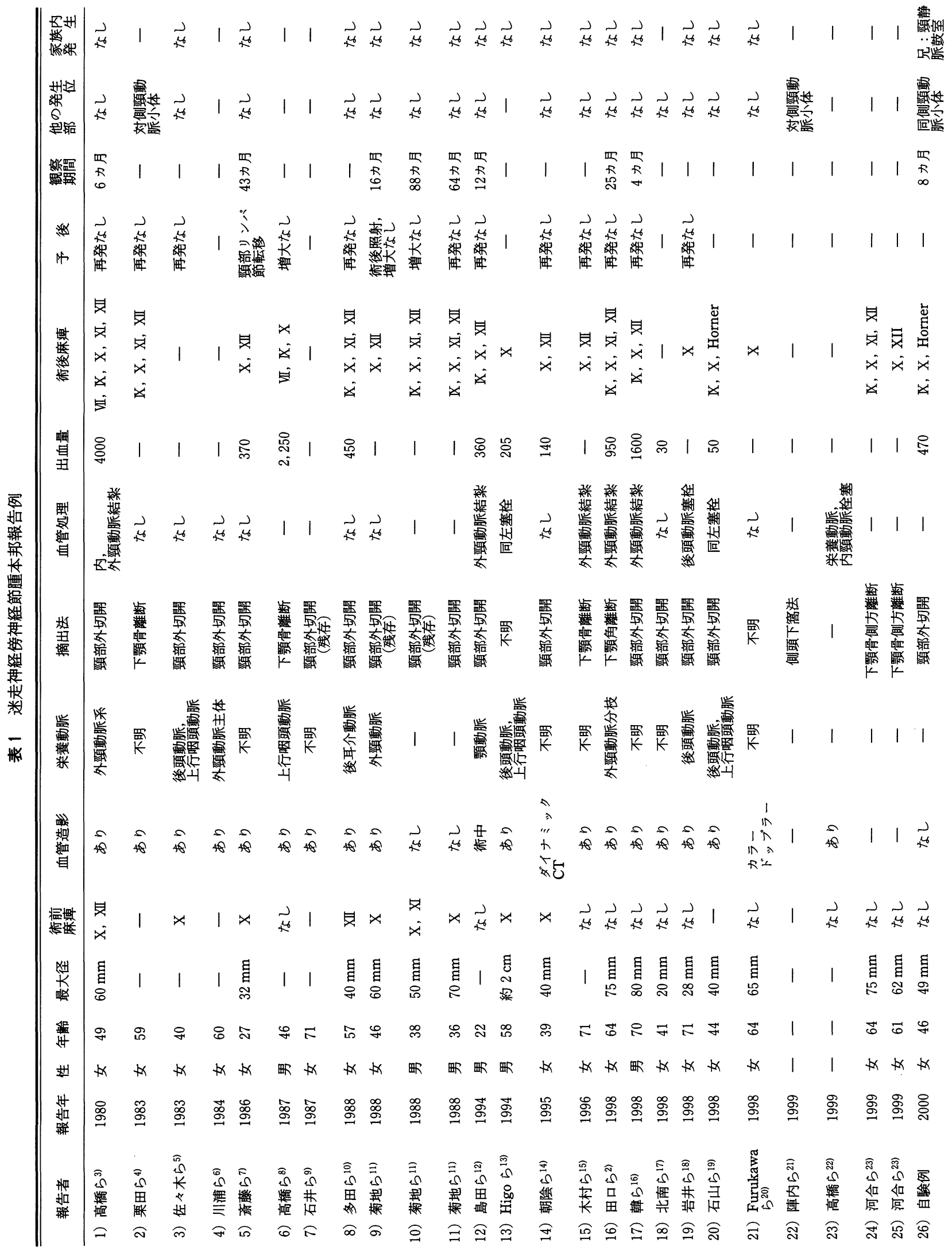


切開のみで摘出可能であった。術前, 術中の血管処理に 関し，術中に頸動脈の結禁を行った例は 5 例あり，ちち 1 例は内頸動脈の結禁を行っていた．術前に塞栓術を 行った例は 4 例であった. 出血量は全体的に多く, 記載 のあった例での平均出血量は約 $840 \mathrm{ml}$ であった．術前 に栄養動脈の塞栓術を行った例のらち, 出血量の記載が あったのは 2 例の久であったが，その出血量はそれぞれ $50 \mathrm{ml}, 205 \mathrm{ml}$ と少量であった. 栄養動脈の術前塞栓は, 出血量を減らすと同時に神経麻㽻などの合併症を抑える 意味でも有用と思われる. 一方迷走神経の処理について であるが，本邦の報告では全例で迷走神経を合併切除し ていた．近年本邦でも神経䩗腫の被膜下摘出が試みられ るようになり，神経麻痺を回避できた報告が散見される ようになったが，傍神経節腫での被膜下摘出の報告はい まだされていない。この理由として，傍神経節腫は易出 血性であるため顕微鏡下に被膜下摘出を行らのが困難で あることが考兄られるが，Miller ら ${ }^{26)}$ は術前に塞栓術 を行い, 術中の出血量を减らした上で腫瘍の被膜下摘出 を行い，声帯麻㽻を回避できた例を報告している．今後 試みるべき方法と思われる。

予後に関しては頸部リンパ節転移をきたした悪性例を 除いて再発，増大を認めた症例はないが，観察期間の短 い症例が多く, 今後の長期的な観察が必要と思われる.

5 ）多発例，家族例

一般に傍神経節腫は家族例，多発例をみることがある とされて扣り，特に頸動脈小体腫瘍では多くの報告がみ られる，海外の報告では迷走神経原発例でも約 $50 \%$ に家 族例をみるとされて赫り，Urquhart ら ${ }^{27)}$ は19例中，多 発性の傍神経節腫が 10 例, 家族例も 9 例に認めたと報告 している. 一方本邦報告例をみてみると，多発例であっ たものは栗田ら ${ }^{4)}$ と陣内ら ${ }^{21)}$ の報告の 2 例のみであり, さらに傍神経節腫を家族内で発症した例は報告されてい なかった．本例は迷走神経に加えて，頸動脈小体にも発 症した多発例であると同時に，兄が頸静脈鼓室傍神経節 腫と家族例を認めたケースでもあり，まれな症例と思わ れる. これらの家族性傍神経節腫について, 近年 Milunsky ら ${ }^{28)}$ は家族性の傍神経節腫をきたす遺伝家系を調べ た結果, 染色体 11 の長腕上にある PGL1 遺伝子が家族 性傍神経節腫に関与している可能性を報告して沏り，さ らに Baysal ら ${ }^{29)}$ は PGL1 遺伝子の中にミトコンドリア の呼吸鎖に関わるタンパクをコードする $S D H D$ 遺伝子 が存在し，この遺伝子の変異が関与している可能性を指
摘している. 近い将来, 傍神経節腫に执いても遺伝子診 断が可能になるかもしれない，今後のさらなる研究が期 待される.

$$
\text { まとめ }
$$

頸動脈小体腫瘍を合併し，家族例がみられた迷走神経 傍神経節腫例を経験し，ともに頸部外切開法で摘出し得 た. 迷走神経を含む傍神経節腫多発例の報告は本邦 3 例 目，家族例の報告は本邦初であった。

稿を終えるに当たり，御校閱御指導賜りました京都大学大学 院医学研究科教授伊藤壽一先生に深謝いたします。

本論文の要旨は第 62 回耳鼻咽喉科臨床学会 (平成 12 年 7 月, 福井)に执いて口演した。

\section{参考文献}

1) 間島雄一: 頸動脈小体腫瘍の診断と治療. JOHNS 11 : 733 738, 1995.

2 ) 田口享秀, 佃 守, 古川正樹, 他: 頸部迷走神経傍神経 節腫の 1 例. 耳喉頭頸 $70: 505 \sim 510,1998$.

3 ) 高橋光明, 海野徳二, 林崎勝武, 他 : Vagal Body Tumor の 1 症例. 日耳鼻 $83: 535,1980$.

4 ) 栗田宣彦, 小高修二, 真島一彦, 他 : Vagal body origin と思われる chemodectoma の 1 症例. 日耳鼻 86:809, 1983.

5 ）佐々木文雄, 古賀佑彦, 竹内 昭, 他: CT 断診が有用で あった vagal body paraganglioma の 1 例. 臨放 $28: 807$ $\sim 810,1983$.

6 ）川浦光弘, 大内利昭, 日下田潔, 他 : 副咽頭腔より発生し たParaganglioma の 1 例. 日耳鼻 $87:$ 1567, 1984.

7 ) 斎藤裕夫, 小野 勇, 海老原敏, 他: 頭頸部領域の傍神経 節腫 -3 例の報告と本邦例の集計一. 耳鼻臨床 $79: 1305$ $\sim 1318,1986$.

8 ) 高橋光明, 林 浩, 金井直樹, 他 : 副咽頭間隙腫瘍の診 断と治療. 耳喉 $59: 617 \sim 623,1987$.

9 ) 石井千佳子, 多田信平 : 傍咽頭間隙腫瘍(副神経節腫). 臨 放 $32: 1423 \sim 1425,1987$.

10）多田 渉, 藤原裕美, 河野嘉彦, 他 : 副咽頭間隙に発生し た paraganglioma の一症例. 耳鼻臨床 補 $27: 110 \sim 114$, 1988.

11）菊地 茂, 喜多村健, 浅井昌大, 他 : intravagal paraganglioma $の 3$ 症例. 耳鼻臨床 $81: 1319 \sim 1326,1988$.

12）島田千恵子, 山口展正, 八代利伸, 他 : 副咽頭間隙に生じ た vagal body tumorの 1 症例. 耳展 $37: 212 \sim 218,1994$.

13) Higo $R$, Asai M, Sugasawa $M$, et al : Preoperative embolization of paraganglioma. Auris Nasus Larynx 21 : 
$122 \sim 125,1994$.

14）朝陰孝弘, 船井洋光, 北原伸郎, 他 : 迷走神経傍神経節腫 -1 例の報告と本邦例集計一. 耳喉頭頸 $67: 676 \sim 679$, 1995.

15）木村隆保, 丸山 晋, 中井 茂, 他 : 迷走神経原生腫瘍 — schwannoma と paraganglioma一. 頭頸部腫瘍 $22: 112$ $\sim 119,1996$.

16）韓 相善, 北村溥之, 高北晋一, 他 : 副咽頭間隙に発生し た傍神経節腫例. 耳鼻臨床 $91: 817 \sim 820,1998$.

17）北南和彦, 高橋光明 : 迷走神経傍神経節腫の 3 症例. 口咽 科 $11: 130 \sim 131,1998$.

18）岩井 大, 喜多 疜, 永田基樹, 他: 迷走神経傍神経節腫 の 1 例. 耳鼻 $44: 255 \sim 258,1998$.

19）石山浩一, 茂木立学, 渡辺佳治, 他 : 副咽頭間隙傍神経節 腫の 1 症例. JOHNS $14: 1381 \sim 1385,1998$.

20) Furukawa M, Furukawa MK, Matsuda $H$, et al : Vagal paraganglioma. ORL $60: 291 \sim 294,1998$.

21）陣内自治, 武田直也, 田村公一, 他 : 迷走神経由来の傍神 経節腫の 1 例. 日耳鼻 $102: 144,1999$.

22）高橋明洋, 椙山久代, 中井淳仁, 他: 迷走神経傍神経節腫 摘出に伴ら内頸動脈切除. 日耳鼻 $102: 768,1999$.

23）河合 敏, 佃 守, 持松いづみ, 他 : Head Rotationを 用いた㬈下訓練の有用性 一最近経験した副咽頭間隙の傍
神経節腫の 3 例から一. 日耳鼻 $102: 311 \sim 316,1999$.

24) Son PM, Biller HF, Lawson $W$, et al : Pharyngeal space masses; an updated protocol based upon 104 cases. Radiology 153 : 149 156, 1984.

25) Arts HA and Fagan PA : Vagal body tumors. Otolaryngol Head Neck Surg 105 : 78 85, 1991.

26) Miller RB, Boon MS, Atkins JP, et al : Vagal paraganglioma; the jefferson experience. Otolaryngol Head Neck Surg $122:$ 482 487, 2000.

27) Urquhart AC, Johnson JT, Myers EN, et al : Glomus vagale ; paraganglioma of the vagus nerve. Laryngoscope $104: 440 \sim 445,1994$.

28) Milunsky J, DeStefano AL, Huang XL, et al : Familial paragangliomas ; linkage to chromosome 11q23 and clinical implications. Am J Med Genet 72 : 66 70, 1997.

29) Baysal BE, Ferrell RE, Willett-Brozick JE, et al : Mutations in $S D H D$, a mitochondrial complex II gene, in hereditary paraganglioma. Science $287: 848 \sim 851,2000$.

$$
\left.\begin{array}{l}
\text { 原稿受付 : 平成 } 12 \text { 年 } 8 \text { 月 } 7 \text { 日 } \\
\text { 原稿採択 : 平成 } 12 \text { 年 } 8 \text { 月 } 23 \text { 日 } \\
\text { 別刷請求先 : 楯谷一郎 } \\
\text { 个606-8507 京都市左京区聖護院川原町 } 54 \\
\text { 京都大学医学部附属病院耳鼻咽喉科 }
\end{array}\right)
$$

